\title{
The Main Changes In Financial Behaviour Of Estonian Firms In Transition Economy
}

\author{
Kaja Lutsoja, (Email: kajd@tv.ttu.edu), Tallinn University of Technology, Estonia \\ Margus Lutsoja, Tallinn University of Technology, Estonia
}

\begin{abstract}
This paper analyzes main changes in financial behaviour of Estonian companies in the period of economic transition in Estonia from 1994 to 2003. Empirical results of Estonian firms' interview study, undertaken annually during 1994-2003, are presented in the paper. We have used other sources in preparation of this paper, which are derived from publicly disclosed statistics of financial institutions and firms. The analyze concentrates on payment habits and terms, as well as on informal borrowing and lending. There exists strong tendency of stabilizing official and habitual payment terms and decrease in informal lending and borrowing. If the informal borrowing was mentioned as an important source of financing in the questionnaires of mid-1990, it has become insignificant in last questionnaires. At the same time the payment habits have became stable and payment terms have slightly decreased.
\end{abstract}

Key Words: firms' financial behaviour, neoclassical theory, post-Keynesian theory sources of financing, contractual obligations, payment terms.

\section{INTRODUCTION}

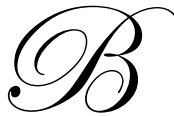

usiness firms operate in a certain environment in which they interact with other firms, individuals, governmental and other institutions, and various interest groups. Legal and institutional issues in the development of the business environment are actual in all countries, especially in emerging market economies in Central and Eastern Europe (CEE). In the conditions of these transition CEE economies not all market structures are yet well-developed and market forces are functioning weakly.

The financial sector, and particularly the banking system played an important role in the process of transition and economic recovery in Central and Eastern European countries (CEECs). Banks and other financial institutions are a unique set of business firms which assets and liabilities, regulatory restrictions, economic functions and operations establish them as an important subject for the study, particularly in the conditions of emerging financial sectors in CEECs. Banks and other financial institutions performance monitoring, analysis and control need special analysis of their operating and activities results. It can be done from the viewpoint of different audiences, like investors/owners, regulators, customers/clients, and banking managers.

There are several obstacles hindering the transformation of former centrally-planned economies into wellfunctioning market economies. The business environment in transition countries is dynamic and dramatically changing (Lavigne 1995).

All these transition activities, such as appropriate institution-building, political democratisation, changes in value appraisal and behaviour of individuals and economic agents, cause rapid changes in the business environment influencing, among others, financing and investment decisions made by firms.

The main objective of this paper is to analyze main changes of financial behaviour of Estonian companies in the period of economic transition in Estonia from 1994 to 2002. This analyze is performed by comparing the proportion of owner's equity to total assets and relation with availability of funds. Empirical results of Estonian 
firms' interview study, undertaken annually during 1994-2003, are presented in the paper. Sample survey methods and some descriptive statistical methods are used for proceeding and analyze initial survey data.

The sample covers the most important industries of Estonian economy; quite typical for a small country, more than one half of manufacturing output is produced in the capital city (at an average 49.2\% in 1994-2000) and surroundings (share of the North-Estonia at an average 28.0\%). Trade industry (at an average $21.5 \%$ ), food industry $(14.2 \%)$ and construction industry $(10.9 \%)$ dominated among industries in the sample.

Other sources used in preparation of this paper are derived from publicly disclosed statistics in respect of financial institutions and availability of different financial instruments. The analyze concentrates on informal borrowing and lending in comparison of average interest rate being applicable on official lending from Estonian commercial banks.

There exists strong tendency of decrease of informal lending and borrowing. If the informal borrowing was mentioned as an important source of financing in the questionnaires of mid-1990, it has become insignificant in last questionnaires. The same can be seen in lending to own employees - together with increase in availability of the loans to "ordinary" people - the lending from employer has decreased.

The most important reasons of informal borrowing, mentioned in the responses in period 1994-1996 were more favourable interest rates and fewer formalities. Together with decrease of market interest rates the first argument has lost its importance. Official lending became competitive together with availability of foreign loans to Estonian commercial banks, which had more resources and were capable to compete with interest rates. It is also important to study the development of financial contractual relationships of firms with their suppliers and clients.

\section{THE CHANGES OF ESTONIAN FIRMS' BEHAVIOUR}

Together with development of overall economic environment the financial behaviour of Estonian firms has changed significantly. These changes have been so quick that sometimes companies do not recognize their own actions to obtain financing, if reminded. The current article describes main changes in the behaviour. Estonian is a small country in which banks are the prevalent financial intermediaries, with total assets accounting over $70 \%$ of GDP (see Table 2).

Table 2: Growth indicators of commercial banks in Estonia

\begin{tabular}{|c|c|c|c|c|c|c|}
\hline \multirow[t]{2}{*}{ Year } & \multirow{2}{*}{$\begin{array}{c}\text { Number of } \\
\text { operating } \\
\text { banks } *\end{array}$} & \multicolumn{2}{|c|}{$\begin{array}{l}\text { Total by the end of the year, } \\
\text { bill. EEK }\end{array}$} & \multicolumn{2}{|c|}{ Per bank, bill. EEK } & \multirow{2}{*}{$\begin{array}{c}\text { GDP (current } \\
\text { prices, bill. } \\
\text { EEK) }\end{array}$} \\
\hline & & assets & share capital & Assets & share capital & \\
\hline 1992 & 41 & 5.2 & 0.5 & 0.13 & 0.01 & 14.3 \\
\hline 1993 & 22 & 6.4 & 0.4 & 0.29 & 0.02 & 21.8 \\
\hline 1994 & 24 & 10.1 & 0.6 & 0.42 & 0.03 & 29.6 \\
\hline 1995 & 18 & 14.9 & 1.1 & 0.83 & 0.06 & 40.7 \\
\hline 1996 & 13 & 21.9 & 1.4 & 1.68 & 0.11 & 52.4 \\
\hline 1997 & 11 & 38.8 & 2.4 & 3.53 & 0.22 & 64.3 \\
\hline 1998 & 6 & 41.0 & 6.1 & 6.83 & 1.02 & 73.3 \\
\hline 1999 & 7 & 47.1 & 6.3 & 6.73 & 0.90 & 75.3 \\
\hline 2000 & 7 & 57.8 & 5.9 & 8.26 & 0.84 & 84.7 \\
\hline 2001 & 7 & 68.4 & & & & 97.9 \\
\hline 2002 & 7 & 81.7 & & & & 108.0 \\
\hline 2003 & 7 & 98.6 & & & & 116.2 \\
\hline
\end{tabular}

* incl. branches of foreign banks

Source: Bank of Estonia.

The role of other financial intermediaries is quite minimal. The four largest banks have more than 95\% shares in Estonian banks' assets, with two of over $80 \%$. Major shareholders in the four largest banks are Nordic 
financial conglomerates, which are also active in other Baltic countries. Estonian banking has experienced two systematic crises, which has significantly decreased the number of banks and has shifted Estonian banking under the control of foreign capital. The same process can be observed in all transition countries where in the end of 1999 foreign banks managed 53\% of assets. Four years ago, the respective number was remarkably lower $-20 \%$. This has also pushed the development of banking regulations and supervision. Profitability and the volatility of profitability of Estonian banks are also declining.

Research on banking reconstruction in Estonia and other Baltic States shows that the major banks of transition economy will reach the level of developed countries' banking in relation to the banks' trustworthiness, novelty of products and standards. This is also a claim of global economy for survival, which has been realized generally by the banking of transition economies. But the disadvantage of such development is the extreme concentration in banking, as a result of which competition, which is essential for ensuring stable development and stability of services and prices in the banking market, will gradually decrease.

In the beginning of 1990-s, Estonia had just became free of planning economy, what efficiently happened in 1989. Although the state has been declared free, the legislative environment and business practice remained comparable to those in other parts of former Soviet Union. Major initiatives from legislative body were related to establishment of monetary system (Law on Estonian Central Bank) and first rules to financial intermediaries. Credit Institutions Act has been approved in 1999, and it has later been modernized several times.

In the following paper are used some results of the special interview study of Estonian manufacturing firms undertaken annually in 1994-1999 and in 2003. Tallinn Technical University research group, headed by prof. Vello Vensel, has monitored Estonian economical behaviour of enterprises in frames of Monitoring of Business Environment.

The study is one part of larger joint research project of analysis of reforms in financial sector in Central and Eastern Europe transition economies. The study was financed by EU Phare program and Estonian Science Foundation support. The sample has not been very large (being during the period of monitoring from 40 to 68 firms), but it is representative in means of composition from different firms.

The main changes are decreasing share of state-owned enterprises and corresponding increasing share of private ownership due to the successful and rapid privatization process, if we compare distribution of firms by the ownership structure in different years. Share of state-owned enterprises (SOE) decreased from $18.1 \%$ in 1994 to $4.1 \%$ in 2000 and correspondingly share of domestically owned private ownership increased from $59.2 \%$ in 1994 to $73.8 \%$ in 2000 we can mention also increase of the share of mixed domestic and foreign private ownership (at an average 16.8\%). The average share of foreign ownership in the last group of firms (12 firms responded in 2000) was $68.3 \%$. Most of the sample firms started their business after 1992 and obtained their start-up financing mostly from own savings (at an average $58.1 \%$ ) because their access to the loan market was limited.

Most of sample firms were medium size firms (at an average 49.6\%) with the number of permanent workers 21-200, share of small firms with the number of workers 1-20 was at an average $37.2 \%$. Quite clear trend was increase of the share of small firms (from 20.6\% in 1994 to $52.9 \%$ in 2000) and respective decrease of the share of large firms (from $23.5 \%$ in 1994 to $4.0 \%$ in 2000). This phenomenon is result of restructuring the whole economy and start-up of new private small businesses. Average number of permanent workers in sample firms was about 50 in 2000 .

As a generalisation, the results show that the sample mostly consists of small (at an average $37.2 \%$ ) and medium-size $(49.6 \%)$ domestically owned private $(73.8 \%)$ joint stock companies $(70.4 \% \%)$ or limited liability enterprises (16.5\%), which started their business on the basis of own savings (58.1\%) after the year $1992(64.1 \%)$, and which are operating in Tallinn (49.2\%) and in North-Estonia (28.0\%). Although the sample is not very big (at an average fifty firms responded every year) it is representative with respect to different distribution characteristics. As a feedback, more important results of the study and a short financial analysis results (for example, Altman Z-score 
and other financial ratios) on the basis of balance sheet and income statement information was given to responded firms.

\section{CONTRACTUAL RELATIONS}

The financial behaviour of firms is closely related to the official financial policy of each country. Part of the financial policy form state-regulated transactions, like tax collection, but the more significant part is always legal framework for civil transactions. In the transition economies, diversification and development of the financial contractual relations of the enterprises have a significant effect on their financial situation. Until 1 July 2002 the main regulative act was Civil Code of Estonian Soviet Republic, after that date it changed to Law of Obligations Act. The effects of this change will become evident only after few years, when it has proven itself as suitable tool in solving business conflicts.

Table 3: Payment terms in Europe in 2001 (days)

\begin{tabular}{|c|c|c|c|}
\hline Country & Average payment term & Average overdue payment & Average real payment time \\
\hline Italy & 65 & 25 & 90 \\
\hline France & 47 & 11 & 58 \\
\hline Belgium & 40 & 21 & 61 \\
\hline Great Britain & 30 & 30 & 60 \\
\hline Austria & 26 & 19 & 45 \\
\hline Switzerland & 22 & 17 & 39 \\
\hline Netherlands & 27 & 19 & 46 \\
\hline Germany & 24 & 18 & 43 \\
\hline Lithuania & 21 & 21 & 36 \\
\hline Latvia & 19 & 17 & 36 \\
\hline Estonia & 16 & 20 & 32 \\
\hline Sweden & 23 & 9 & \\
\hline
\end{tabular}

Source: Krediidiinfo AS

The example of payment terms in course of ordinary business relations of sales and purchases can be put into cadre in comparison of different countries' habits. The study is part of the larger research made by Intrum Justitia.

Payment terms are related to the availability of credit insurance. For example, in Lithuania, where the credit insurance is freely available, the real payment terms are 42 days in average. At the same time, in Latvia and Estonia, where no credit insurance system is in place, the average payment term is 36 days. At the same time, Estonia has significant availability of factoring. According to AS Hansa Capital, the largest lease and factoring provider in Estonia, the factoring turnover of 3 major Estonian banks (Hansa, Ühispank, Sampo pank) in 2002 has increased $42 \%$ compared to 2001 . The popularity of financing by factoring can be demostrated by the fact that the market share of factoring is one of the highest in the world in Estonia, reaching 14\% of GDP. In comparison the same ratio in the more matured countries, like in Italy and UK is $10 \%$ and in other new members of the European Union like Poland and Chech Respublic is 2\% (SEB Estonian Union Bank).

Estonian companies have become more satisfied with payment practice of the customers during last years (see Table 4). The share of companies where the respondents were satisfied in general with the payment practice of customers has increase from 34,5\% in 2002 to 50,0\% in 2004 whereas the share of respondents ho were not satisfied varied from $2,0 \%$ to $3,8 \%$. 
Table 4: Changes in satisfaction with payment practice of customers

\begin{tabular}{|c|c|c|c|c|}
\hline & Satisfied in general & $\begin{array}{c}\text { More satisfied than } \\
\text { not }\end{array}$ & $\begin{array}{c}\text { Less satisfied than } \\
\text { satisfied }\end{array}$ & Not satisfied \\
\hline $\mathbf{2 0 0 4}$ & $50.0 \%$ & $32.1 \%$ & $14.1 \%$ & $3.8 \%$ \\
\hline $\mathbf{2 0 0 3}$ & $22.2 \%$ & $37.5 \%$ & $33.3 \%$ & $7.0 \%$ \\
\hline $\mathbf{2 0 0 2}$ & $34.5 \%$ & $49.0 \%$ & $14.5 \%$ & $2.0 \%$ \\
\hline
\end{tabular}

Source: Krediidiinfo AS, (modified by authors)

There is a relation with publicity. The bad payment practice is often made public by work of different debt collecting companies, public "black lists" and public information in internet. Most of the companies first researches background of the potential partner than starts business. According to the market research of credit policy of Estonian companies, 51,5\% of companies always researches background of partner and 33,3\% does it frequently. Only 4,4\% does not research background of the partner. The main information, what is collected, is registration data of partners and signers' authority (58\% and 32\% respectively). The most important information used in making credit policy decisions, is payment practice of potential partner and its general reputation (42\% and 54\% respectively).

Figure 1: Changes in satisfaction with payment practice of customers

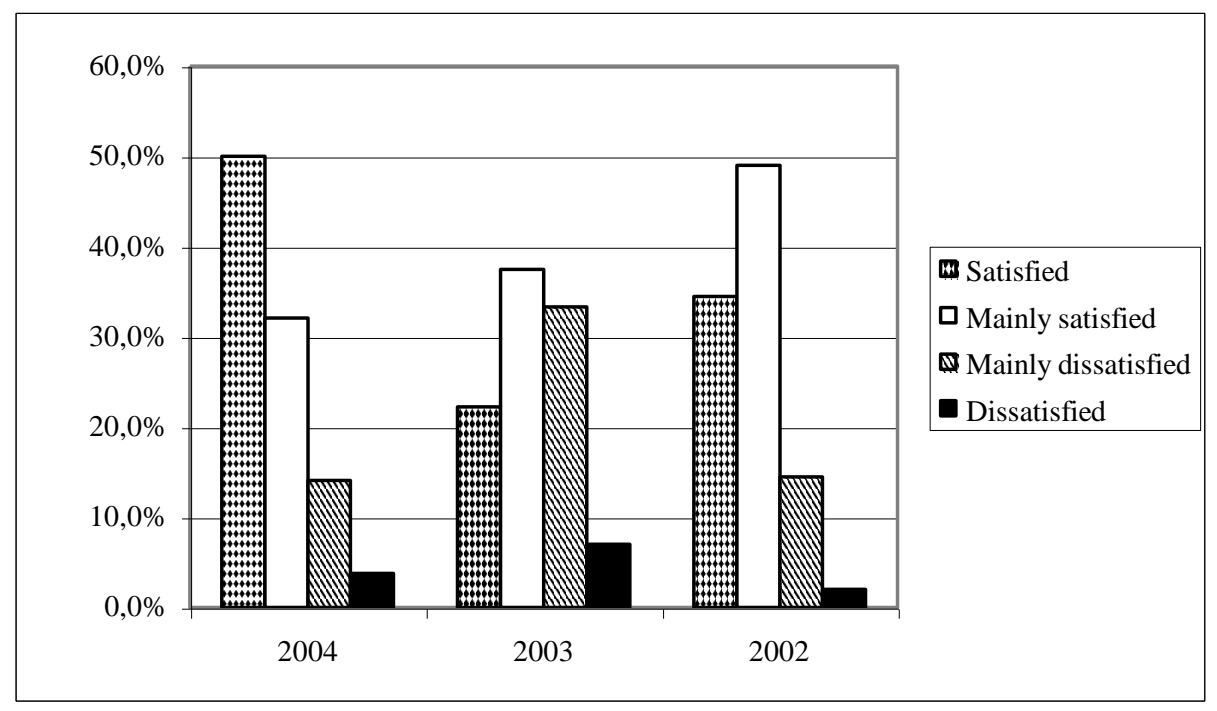

5.

In average, in 2002 the companies gave payment terms (days from issuing the invoice) as follows in Table

Table 5: Changes in average payment terms given by companies

\begin{tabular}{|c|c|c|c|c|c|c|c|}
\hline & Prepayment & $\mathbf{1 - 7}$ days & $\mathbf{8 - 1 4}$ days & $\mathbf{1 5 - 3 0}$ days & $\mathbf{3 1 - 6 0}$ days & $\begin{array}{c}\text { 31- more } \\
\text { than 90 } \\
\text { days }\end{array}$ & $\begin{array}{c}\text { At } \\
\text { realisation } \\
\text { of the goods }\end{array}$ \\
\hline $\mathbf{2 0 0 4}$ & $11.2 \%$ & $16.8 \%$ & $30.7 \%$ & $33.5 \%$ & $2.8 \%$ & $0.6 \%$ & $4.4 \%$ \\
\hline $\mathbf{2 0 0 3}$ & $7.0 \%$ & $20.8 \%$ & $23.0 \%$ & $31.3 \%$ & $10.2 \%$ & $2.3 \%$ & $5.4 \%$ \\
\hline $\mathbf{2 0 0 2}$ & $16.3 \%$ & $20.1 \%$ & $20.9 \%$ & $33.8 \%$ & $4.9 \%$ & $2.1 \%$ & $1.9 \%$ \\
\hline
\end{tabular}

Source: Krediidiinfo AS, 
During the period under consideration, the changes related to the solving of payment disputes were as follows in table 6 .

Table 6: Disputes With Clients (\%)

\begin{tabular}{|c|c|c|c|c|c|c|c|c|}
\hline Disputes Characteristics & $\mathbf{1 9 9 4}$ & $\mathbf{1 9 9 5}$ & $\mathbf{1 9 9 6}$ & $\mathbf{1 9 9 7}$ & $\mathbf{1 9 9 8}$ & $\mathbf{1 9 9 9}$ & $\mathbf{2 0 0 0}$ & $\mathbf{2 0 0 3}$ \\
\hline Late payment problems (share) & 92.1 & 88.2 & 87.3 & 81.3 & 89.4 & 85.1 & 83.0 & 80.6 \\
\hline Non-payment problems (share) & 66.7 & 70.1 & 68.9 & 69.1 & 71.9 & 71.1 & 74.0 & 66.3 \\
\hline Resolution of disputes: & & & & & & & & \\
\hline Usage of direct bargaining & 100 & 96.2 & 93.8 & 80.0 & 88.1 & 94.7 & 93.3 & 90.3 \\
\hline Usage of private arbitrage & - & - & 5.0 & 2.5 & 3.7 & 5.3 & 4.3 & 3.0 \\
\hline Threat to turn to the policy & 6.5 & 13.2 & 10.5 & 12.8 & 15.8 & 5.3 & 23.9 & 12.6 \\
\hline Usage of a lawyer & 32.1 & 34.2 & 39.4 & 21.1 & 35.6 & 29.7 & 42.2 & 43.5 \\
\hline Threat to turn to the court & 41.4 & 36.7 & 42.1 & 27.5 & 37.0 & 36.8 & 46.7 & 41.3 \\
\hline Share of settled disputes & 63.0 & 54.3 & 55.5 & 50.0 & 59.3 & 52.6 & 64.4 & 57.0 \\
\hline Satisfaction with the outcome & 51.6 & 52.2 & 44.4 & 43.6 & 54.2 & 47.4 & 53.3 & 59.5 \\
\hline Still doing business with other party & 60.6 & 48.9 & 38.9 & 40.7 & 54.2 & 36.8 & 64.3 & 52.2 \\
\hline
\end{tabular}

Source: Authors' calculations (see also Vensel and Vensel, 2001).

We can see that in the same time when the share of settled disputes remained on the same level, the ways of solving the disputes have been changed. The share of direct bargaining is dropping and the use of legal possibilities has increased. This is again indicating us that the financial behaviour is related to the general economy. Years of financial growth have given to Estonia a possibility to become more stable and regulated.

As the Estonian general principles of solving disputes between the companies are based on written contracts and legal actions, the share of written contracts is increasing. From the other side there is no information on efficiency of legal actions. External suppliers (outside Estonia) do not have agreements as additional instruments to secure them therefore the share of written contracts with suppliers is lower.

The involvement level in solving the payment disputes has became higher in period from 2002 to 2004 . Involvement of CEO has reached $90 \%$ of cases. The connection with the result shown on Figure 1 is likely, as if the cases of late payment or breaching of credit limits became rare, each remaining case obtains more importance.

Figure 2: Involvement of different level managers in solving credit disputes in Estonian companies.

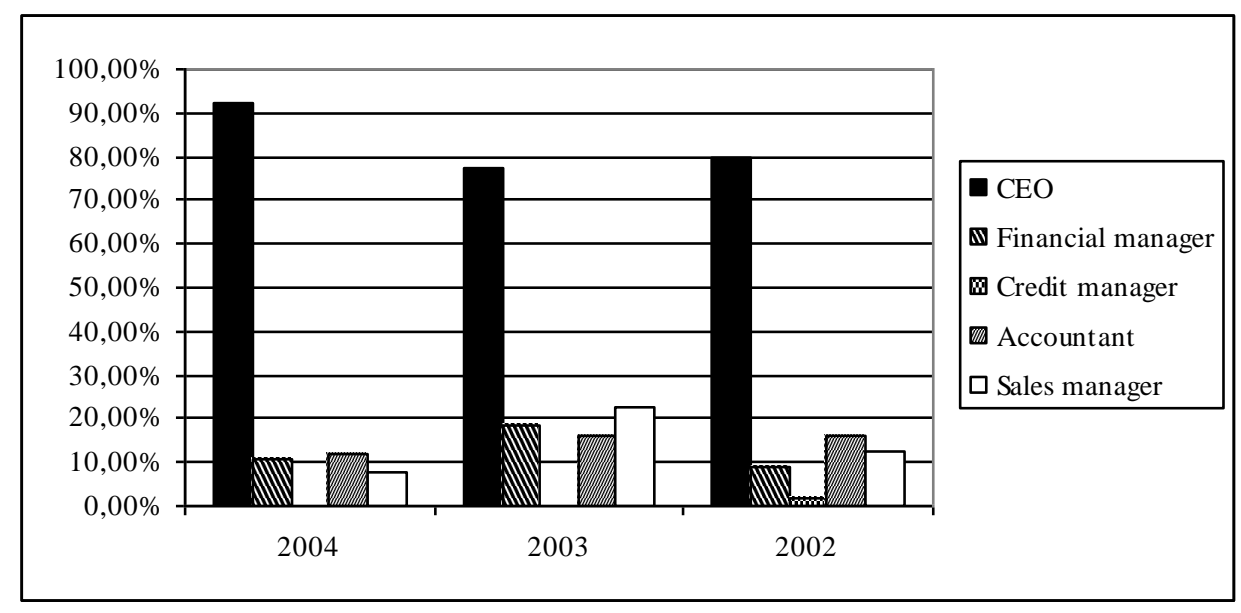


We can observe also that together with the increase in satisfaction with payment practice the level of respondents who always check the background of customers has decreased (Figure 3). Some part in it has smallness of Estonia, where the business community generally knows each other, so the need for checking background has switched from "Always" to "Sometimes", but the share of "Never" has increased as well.

Figure 3: Frequency of checking new customers' background by Estonian companies in 2002 to 2004

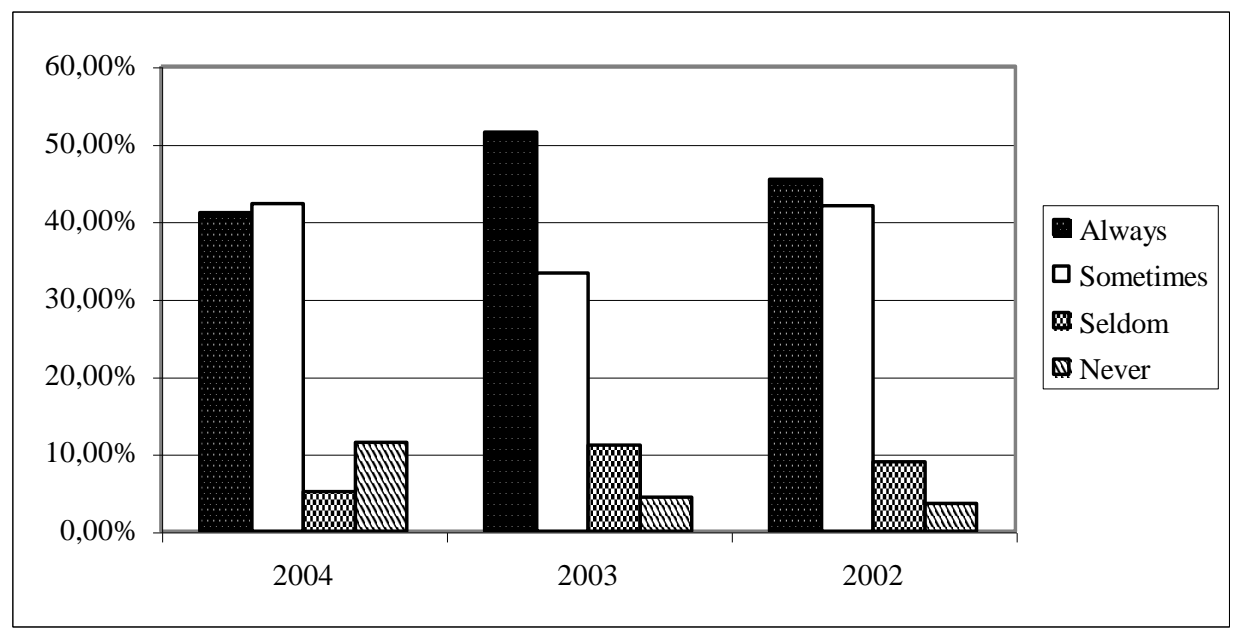

\section{BORROWING AND LENDING} in Table 7.

Sources of financing in the period under consideration have also had some changes. The results are presented

Table 7: Sources of financing of Estonian Firms in 1994-2000, percentage of total

\begin{tabular}{|c|c|c|c|c|c|c|c|c|}
\hline Source of financing & $\mathbf{1 9 9 4}$ & $\mathbf{1 9 9 5}$ & $\mathbf{1 9 9 6}$ & $\mathbf{1 9 9 7}$ & $\mathbf{1 9 9 8}$ & $\mathbf{1 9 9 9}$ & $\mathbf{2 0 0 0}$ & $\mathbf{2 0 0 3}$ \\
\hline Own savings & 57,9 & 63,6 & 51,6 & 57,4 & 50,3 & 56,3 & 69,7 & 60,1 \\
\hline Loan from domestic bank & 10,5 & 11,4 & 10,9 & 1,0 & 6,2 & 5,7 & 3,5 & 10,1 \\
\hline Loan from relatives, friends & 8,0 & 9,2 & 6,2 & 3,3 & 1,9 & 6,5 & 2,7 & 1,6 \\
\hline Loan from foreign bank & 2,6 & 6,8 & 1,6 & 0,8 & 0,6 & 1,4 & 0,8 & 1,1 \\
\hline Loan from money-lender & 10,5 & 4,5 & 4,7 & 3,7 & 1,5 & 2,2 & 1,1 & 1,0 \\
\hline Other sources & 10,5 & 4,5 & 25,0 & 33,7 & 39,5 & 27,9 & 22,2 & 26,1 \\
\hline
\end{tabular}

Some of the results from the table 7 can be directly attributed to the tendencies in overall economy, e.g. increase of borrowing from relatives and friends increased in 1999, a year after financial sector has been hit by Russian crisis. Importance of other sources is also indicative of foreign investments to the Estonian companies.

Getting a loan from an Estonian Commercial Bank depends on loan guarantees, total assets of the company and the time how long the company has been client of the bank.. As the companies do not have sufficient guarantees at starting the business it is extremely difficult to access credit resources through bank loans. This is why the starting capital has been mainly collected from own savings, more than a half of resources of starting capital every year. Borrowing from moneylenders is not typical and that service does not have significant influence on financial market. 
Also, together with increase of availability of formal lending from banks, the importance of lending from moneylenders has decreased. One of the reasons is their higher interest margins; another is their reputation of informal way of debt collection, if the payments were delayed.

Interesting fact is, that despite of increase of availability of formal lending, importance of own savings (including owners' equity) has remained high. It may be related to the "long-term survival" goal of managers. Somewhat this indicates trust of Estonian owners and managements to the business: only small percent of companies have distributed dividends. Taking financial obligations is still seen as more risky strategy than having large owners' equity.

Estonian income tax law supports having more equity in business. Because the income in the company is not taxed, there does not exist usual income tax effect on borrowing and the profit of Estonian subsidiary of international group, if consolidated into parents' result, makes groups average income tax level lower. From one side it is disadvantageous to the lenders in banks, but the effect on total economy probably outweighs this disadvantage. The same reason may be behind the aggressive lending to private persons: there simply may not be enough business to whom to lend the funds.

\section{FINANCIAL CONTRACTUAL RELATIONS}

About half of the interviewed companies reported usage of overdraft facilities, most of them received overdrafts from one bank (81\%) and others from 2 different banks (see Table 8).

Table 8: Borrowing from Formal Institutions

\begin{tabular}{|c|c|c|c|c|c|c|c|}
\hline Share of firms (\%) using: & $\mathbf{1 9 9 4}$ & $\mathbf{1 9 9 5}$ & $\mathbf{1 9 9 6}$ & $\mathbf{1 9 9 7}$ & $\mathbf{1 9 9 8}$ & $\mathbf{1 9 9 9}$ & $\mathbf{2 0 0 3}$ \\
\hline Overdraft facilities & 41.9 & 42.9 & 45.5 & 56.3 & 43.3 & 45.7 & 42,7 \\
\hline Granted loans & 33.3 & 38.7 & 47.9 & 55.1 & 50.7 & 63.8 & 65,5 \\
\hline Leasing contracts & 22.2 & 32.6 & 47.5 & 60.0 & 68.7 & 61.4 & 62,3 \\
\hline Share of bank loans (by number) & 76.9 & 74.3 & 75.2 & 74.8 & 73.3 & 65.0 & 73,1 \\
\hline Average annual interest rate & 24.6 & 18.2 & 16.7 & 16.6 & 12.4 & 12.1 & 8,1 \\
\hline Share of firms applying for loans, \% & 36.8 & 47.2 & 62.5 & 51.1 & 52.2 & 42.2 & 61.2 \\
\hline Share of accepted loan applications, \% & 92.9 & 89.1 & 76.6 & 88.0 & 82.9 & 89.5 & 94.3 \\
\hline Reasons why the firm did not apply: & & & & & & & \\
\hline High interest rates & 37.3 & 3.9 & 27.3 & 7.4 & 10.8 & 16.0 & 7.5 \\
\hline Do not wish to fall into the debt & 20.8 & 19.2 & 27.3 & 18.5 & 10.8 & 4.0 & 4.1 \\
\hline Do not need a loan & 16.7 & 42.3 & 36.4 & 40.7 & 56.7 & 48.0 & 52.2 \\
\hline Complicated application procedure & 8.4 & 11.5 & 9.0 & 3.8 & - & - & 1.0 \\
\hline
\end{tabular}

Part of lease financing has steady growth from 1994 to 1998. That can be explained with general legislation enabling to secure leases in better way than loans. Granted loans have been used more in late 90 -s and were even more popular than financial leases in 1999.

Approximately an half of the companies has requested a loan from bank and nine tenths had received it. Firms, who received loans during the last year or during the last five years, reported more exact terms and conditions of loans. About $2 / 3$ of institutional loans were bank loans, firms received loans also form non-bank financial institutions (for example, from credit unions), from government projects and foundations, from parent firms. The companies what did not apply the loan majority did not need financing outside the company. The second most important reason was lack of security to be pledged as collateral.

\section{INFORMAL BORROWING AND LENDING}

23.4\% responded firms reported the usage of informal borrowing during last 3 years. The main reasons for informal borrowing (mainly fewer formalities and more favourable interest rate) are presented in the Table 9. 
Relatives and friends, also owners and parent firm, were reported as main loan sources, moneylenders and suppliers or clients were also mentioned. To comment informal borrowing the most adequate conclusion is that personal relationship with the borrower is a reason why it is used.

Table 9: Informal Borrowing and Lending

\begin{tabular}{|c|c|c|c|c|c|c|c|}
\hline Reasons & 1994 & 1995 & 1996 & 1997 & 1998 & 1999 & 2003 \\
\hline \multicolumn{8}{|l|}{ 1. Informal Borrowing: } \\
\hline Share of firms using informal borrowing & 18.7 & 21.2 & 16.7 & 24.5 & 23.9 & 23.4 & 20.3 \\
\hline \multicolumn{8}{|l|}{ Main reasons of informal borrowing: } \\
\hline More favourable interest rate & 33.3 & 41.6 & 12.5 & 8.3 & 37.5 & 36.4 & 13.2 \\
\hline More flexible repayment schedule & 16.7 & 25.0 & 25.0 & 58.4 & - & - & - \\
\hline Less formalities & 33.3 & - & 25.0 & - & 31.3 & 54.5 & 66.9 \\
\hline Collateral is not needed & - & 16.7 & 25.0 & 8.3 & 12.5 & 9.1 & 15.3 \\
\hline Others (did not got a loan from a bank) & 16.7 & 16.7 & 12.5 & 25.0 & 18.7 & - & 4.6 \\
\hline \multicolumn{8}{|l|}{ Main loan sources/lenders: } \\
\hline Relatives and friends & 50.0 & 58.3 & 37.5 & 50.0 & 77.4 & 36.4 & 61.0 \\
\hline Money-lenders & 16.7 & 16.7 & 25.0 & 16.7 & 12.9 & 18.2 & 15.2 \\
\hline Informal groups & - & 16.7 & 25.0 & 16.7 & 3.2 & - & - \\
\hline Suppliers or clients & - & 8.3 & 12.5 & - & - & 18.2 & 18.1 \\
\hline Others (individuals, parent firm) & 33.3 & - & - & 16.6 & 6.5 & 27.2 & 5.7 \\
\hline Average annual interest rate & 28.4 & 22.3 & 19.8 & 16.3 & 11.1 & 8.1 & 8.4 \\
\hline Usage of collateral, $\%$ & 16.7 & 22.5 & 37.5 & 25.0 & 25.0 & 9.1 & 10.3 \\
\hline \multicolumn{8}{|l|}{ 2. Informal lending: } \\
\hline Share of firms granted informal loans & 23.0 & 34.2 & 29.6 & 35.8 & 37.3 & 31.1 & 29.6 \\
\hline \multicolumn{8}{|l|}{ Main loan recipients: } \\
\hline Relatives and friends & 14.8 & 27.8 & 5.3 & 3.2 & 8.0 & 14.3 & 3.3 \\
\hline Suppliers or clients & 14.8 & - & - & 17.4 & 12.0 & 14.3 & 14.4 \\
\hline Employees & 48.2 & 55.6 & 73.7 & 76.7 & 60.0 & 57.1 & 69.8 \\
\hline Other firms & 22.2 & 16.6 & 21.0 & 2.7 & 20.0 & 14.3 & 12.5 \\
\hline Average annual interest rate & 23.5 & 18.6 & 15.4 & 11.3 & 9.9 & 8.8 & 8.2 \\
\hline Usage of collateral, $\%$ & 33.3 & 28.4 & 47.4 & 21.7 & 38.1 & 46.1 & 55.2 \\
\hline
\end{tabular}

Largest share in money lending have employees. It is probably related to policy of retaining employees in the business when salaries are relatively low. Although loans from banks have become available to many persons, lending from a company is still popular.

An important component of a state's economic policy is its financial policy. The financial sector, and particularly the banking system played an important role in the process of transition and economic recovery in Central and Eastern European countries (CEECs). Banks and other financial institutions are a unique set of business firms which assets and liabilities, regulatory restrictions, economic functions and operations establish them as an important subject for the study, particularly in the conditions of emerging financial sectors in CEECs. Banks and other financial institutions performance monitoring, analysis and control need special analysis of their operating and activities results. It can be done from the viewpoint of different audiences, like investors/owners, regulators, customers/clients, and banking managers.

There are several obstacles hindering the transformation of former centrally-planned economies into wellfunctioning market economies. The business environment in transition countries is dynamic and dramatically changing. All these transition activities, such as appropriate institution-building, political democratisation, changes in value appraisal and behaviour of individuals and economic agents, cause rapid changes in the business environment influencing, among others, financing and investment decisions made by firms. 


\section{CONCLUSIONS}

This paper's main objective was analyzing of most significant changes of financial behaviour of Estonian companies in the period of economic transition in Estonia from 1994 to 2002. As a significant part of financial behaviour, credit sales and debt collecting were analyzed and the following items cleared:

- $\quad$ The perceived payment practice in Estonia has improved in period 2002 to 2004. Actual receipt of money by seller in Estonia is quicker than in Europe in average.

- The level of mangers who are involved in solving late payment or non-payment problems has risen and in more than $90 \%$ of cases highest level manager is involved.

- $\quad$ Companies have used more legal possibilities (e.g. turning to court) to solve different disputes, when the share of direct bargaining is decreasing. The probable cause of this tendency is stabilising of economy and increased satisfaction with the outcome.

- $\quad$ Formal lending is more popular and the main reason why companies did not apply for a loan is that they did not need it. It seems that the companies are financing itself more by own equity and they do not apply for a loan without clear need. This is seen from different sources: from answers to a question "why did not apply for a loan", but also from responses to the source of financing question - most popular selection was "own savings", including retained earnings.

- $\quad$ Based on preliminary data, the decrease in interest rates has had effect on borrowing: more companies are either taking loans or leasing assets through financial institutions.

- $\quad$ There is evidence of change in financial behaviour of Estonian companies to switch from informal borrowing to formal one. Together with increase of Estonian banks the clients of those, companies, are more using different financial facilities.

- Despite availability of formal loans, informal lending has remained stable. In our opinion, the main reason is employer's wish to bind employees to the company, but other explications may also be relevant. The research gives interesting and important data about financial behaviour of Estonian firms.

\section{REFERENCES}

1. Gordon, M.J. 1994. Finance, Investment and Macroeconomics - The Neoclassical and a Post Keynesian Solution.

2. Krediidiinfo AS. www.krediidiinfo.ee/stats turuuuring 2003.html, www.krediidiinfo.ee/stats turuuuring_2002.html, www.krediidiinfo.ee/stats turuuuring 2004.html

3. Lavigne, M., 1995. The Economics of Transition. From Socialist Economy to Market Economy. New York, $1995,295 \mathrm{p}$

4. Mramor, Dusan and Aljosa Valentincic. 1994. Keynesian Solution. www.departments.bucknell.edu/management/ apfa/papers/06Mramor.pdf/ 24.04.2003

5. Mramor, Dusan and Aljosa Valentincic. 2003. Financial behavior of slovenian firms. Faculty of Economics, University of Ljubljana http//www.ef.uni-lj.si/predmeti/finmanagement/ Financial\%20Behavior_Mramor.pdf/24.04.2003

6. $\quad$ Portfolio. Ühispanga infoleht ärikliendile. http://www.eyp.ee/?page=101016

7. Traditional, modern and new approach to finance. http://www.departments.bucknell.edu/management/apfa/Hamburg\%20Papers/Mramor.pdf

8. Teearu, Asta and Vello Vensel. 2001. Development of Financial Contractual Relations in Estonian Economy. In: V. Vensel and C. Wihlborg, eds. Estonia on the Threshold of the European Union: Financial Sector and Enterprise Restructuring in the Changing Economic Environment. Tallinn: Tallinn Technical University, pp. 207-222.

9. Vensel, Lia and Vello Vensel.2001. Operation of the Conflict Resolution Mechanism and Business Supporting Services. In: V. Vensel and C. Wihlborg, eds. Estonia on the Threshold of the European Union: Financial Sector and Enterprise Restructuring in the Changing Economic Environment. Tallinn: Tallinn Technical University, pp. 257-274. 